\title{
Schack och social interaktion
}

\author{
Dag Østerberg, Johan Asplund och brädet
}

\begin{abstract}
Chess and social interaction. Dag Østerberg, Johan Asplund and the board
What can a theory of chess learn from sociology? And what can sociology learn from chess? This article examines the contribution of Scandinavian sociologists Dag Østerberg and Johan Asplund on chess and sociology in order to better understand chess and, to some degree, the sociologies of Østerberg and Asplund. Developing the concept of tertius as a necessary third quasi actor mediating between ego and alter, the article also contributes to a general sociological theory of games. The game is analysed as a form of interaction where each player plays (i) with tertius against the opponent, and (ii) with the opponent against tertius. The article ends by arguing that tertius could be a valuable concept for sociological theory.
\end{abstract}

Keywords: game, play, social psychology, sociology, tertius, theory

\section{Tertium datur! Det gives (alltid) ett tredje!}

SCHACK ÄR ETT spel vars dragningskraft inte påverkar alla i lika hög grad. Så är det till exempel ett välkänt faktum att schackvärlden är utpräglat manlig (Desjarlais 2011:139-143; Fine 2015:164-167; Gobet 2019:55-64; Galitis 2002; jämför även Shahade 2005), något som föga förvånande har uppmärksammats av psykoanalytiskt orienterade författare (Cockburn 1975; Fine 1956; 1973:83; men se också kritiken i Fine 2015:164-165; Gobet 2019:61-62). Vidare har spelets gravitation en klassdimension. I Europas historia kan man till exempel följa schackets klassresa från det spanska hovet på 1400-talet, via borgerliga caféer och klubbar på 1700-och 1800-talet, till 1900-talets arbetarschack å ena sidan, och professionella turneringar å den andra (Eales 1985; Petzold 1986). Men också alldeles bortsett från dessa och liknande sociologiskt variabla aspekter tycks Caïssa, schackets pseudoantika gudinna, lämna vissa oberörda, medan andra, mer eller mindre motvilligt, skänker henne sin tribut.

Och sociologin? Ja, den har i ganska stor utsträckning hållit sig borta från schack. Medan till exempel psykologin länge har studerat schack ur ett traditionellt kognitivt perspektiv (Gobet 2019), kognitionsvetenskapen ofta använt schack som en modell i försöken att utveckla artificiell intelligens (Ensmenger 2012), nationalekonomin använt sig av schack för att undersöka riskbenägenhet (se till exempel Gerdes \& Gränsmark 
2010) och medan pedagogiken på senare tid ägnat åtskillig möda åt att kartlägga den av många önskade men efter vad det verkar tveksamma nyttan av schackspelande sett ur ett lärandeperspektiv (Sala \& Gobet 2016, 2017), så är den mer snävt sociologiska litteraturen om schack begränsad (jämför Puddephatt \& Fine 2013). Den litteratur som ändå finns är i stor utsträckning symboliskt interaktionistiskt och etnografiskt orienterad och undersöker ofta den faktiska sociala interaktionen över schackbrädet också online och per korrespondens - och i schackklubbar (Fine 2015; Persson 2015; Aycock 1990, 1992; Bernard 2003; Desjarlais 2011; Puddephatt 2008), och den kan härvidlag i någon mån kompletteras med sociologiskt relevanta, etnografiskt orienterade och många gånger djupt inträngande journalistiska arbeten (Hallman 2003; Hoffman 2007; Weinreb 2007). Enligt min uppfattning är Robert Desjarlais' Counterplay (2011) och Gary Fines Players and pawns (2015) de enskilt viktigaste bidragen på detta område. Ett särskilt tema i litteraturen är vidare schackspelande som en form av strategiskt handlande (Leifer 1988; Puddephatt 2003), och här finner man en viss kritik mot en snävt spelteoretisk uppfattning av schack.

Föreliggande artikel gör inte anspråk på att studera schack eller schackets värld i hela dess mångfald och rikedom. Perspektivet är tvärtom på sätt och vis tämligen begränsat. Dels är frågorna som behandlas i huvudsak teoretiskt orienterade med fokus på strukturen på schackspelandets sociala interaktion, dels utgörs föremålet för arbetet av två tidigare publicerade arbeten om schack. Det gäller den norske sociologen Dag Østerbergs uppsats "Sosial interaksjon og spillteorin. Sjakkspillets eksempel” (1993e) och den svenske sociologen Johan Asplunds kapitel "Schack" ur boken Genom huvudet. Problemlösningens socialpsykologi (2002:83-93). Østerberg och Asplund, som hör till de mer välkända och inflytelserika sociologerna i Norge och Sverige (se till exempel Otnes 2006; Eriksson 2005), analyserar i dessa texter olika aspekter av schack och social interaktion. Men texterna står också i ett särskilt inbördes förhållande till varandra, då nämligen Asplunds text i mycket utgör en kritik av Østerbergs. Jag avser i detta arbete att i detalj analysera dessa texter, och jag gör det i syfte att undersöka Østerbergs respektive Asplunds syn på schack som social interaktion och hur de förhåller sig till varandra. Förhoppningsvis kan resultatet av denna jämförelse också säga något mer allmänt om schack, om spel och om social interaktion överhuvudtaget.

Om arbetets upplägg vill jag framhålla två saker. Den ena gäller disposition/metod. Jag kommer först att analysera Østerbergs bidrag. Sedan går jag över till Asplunds och analyserar först hans förståelse av schack, sedan hans kritik av Østerbergs position. Detta följs av en avslutande del som relaterar analysen till olika teorier om spel och mer allmänt till social interaktion. Den andra saken gäller arbetets metod/ambition. Den övergripande tanken är att inte bara Østerberg och Asplund skall spela mot och med varandra i ett slags sociologiskt schackparti, utan också att sociologi och schack i någon mån skall förmås att spela mot och i bästa fall samtidigt också med varandra. Schack utgör här förvisso hela tiden - hos Østerberg, hos Asplund och i detta arbete - ett exempel i en större sociologisk diskussion om spel och interaktion, men min avsikt är att det inte enbart skall vara ett exempel, utan att schackets egenart också i någon mån skall undersökas och belysas (jämför Huzinga 2001:10; Henricks 2015:6). 


\section{Østerberg om spelteorins gränser}

Østerberg har sedan sina tidigaste arbeten intresserat sig för olika former av social handling (Østerberg 1977a, 1993d). Han har också flera gånger skrivit om spelteoretiska frågor och försökt bestämma gränserna för matematiska, spel- eller bytesteoretiska angreppssätt i sociologin (Øfsti \& Østerberg 1982; Østerberg 1988, 1993a, 1993d, 1993f, 2011). I det arbete som här behandlas gör han det med hjälp av en analys av schackspel. Vad Østerberg vill visa är att spelteorin (alltså det som på engelska går under beteckningen game theory; jämför Swedberg 2001) inte, vilket man ibland har hoppats på, skulle kunna vara "den almene teorien om sosial interaksjon, og dermed bli i stand til å forene alle samfunnsvitenskapene til ett emneområde" (1993e:195). Hur skulle nu den som ville hävda något sådant kunna resonera?

De som går inn for spillteorien kan gjenomføre denne tankegangen: Spillteorien er en omforming av sosial interaksjon ved hjelp av begrepet om forholdet mellom mål og middel. Forbildet eller urbildet er spillet, med sine regler, spillere og deres strategier. Spillteorien undersøker hvordan interaksjonen ville forløpe dersom spillerne handlet så rasjonalt (forstandig) som mulig ut fra mål/middelskjemaet. Kan det finnes rasjonalitet i et interaksjonsforløp hvor spillerne tar med i beregningen hverandres gjensidige strategier? Dette spørsmålet har ført til letingen etter såkalte "likevektspunkter", som er blitt påvist å finnes i et antall situasjoner. I vanlige spill er formålet klart. Spillerne prøver å vinne, deres interesser er forskjellige fra hverandre. Nytten av mulige handlingsalternativer kan derfor fastslås i prinsippet. Videre går det an å almengjøre grunnbegrepene om spillere, nytte og strategi til interaksjonsforløp som strengt tatt ikke er spill. De fortolkes som spillignende forløp. Neste trinn er å vise at konkurransepreget ved spill ikke er et vesenstrekk, siden det også finnes samarbeidsspill. Til sist kan all slags sosial interaksjon undersøkes fra den rasjonelle strategiens synspunkt (1993e:195).

Østerberg menar nu att det är enkelt att påvisa problemet med denna tankegång. Han diskuterar först tre exempel på former av social interaktion vilka alla motstår eventuella försök att analyseras spelteoretiskt. Det första gäller moraliskt handlande. Det moraliska sammanhanget karakteriserar Østerberg som ett sammanhang där aktörerna har internaliserat gemensamma värdemåttstockar och symboler och där de bedömer varandra och sig själva utifrån vad som är moraliskt rätt; förgäves skulle en person här försöka rättfärdiga sitt handlande genom att hänvisa till en eventuell nytta - tvärtom vore ett sådant försök i dessa sammanhang att betrakta som omoraliskt. Østerberg talar, med hänvisning till jämviktsbegreppet inom spelteorin, om den moraliska situationen som en situation med en "'bevegelig likevekt' rundt en normativt bestemt situasjon som skal bevares eller oppnås" (1993e:196). Det andra exemplet som Østerberg anför är det kollegiala samtalet, som till skillnad från den (sociologiskt betraktat) moraliska situationen utgör "et åpent system" (1993e:196). Detta är, idealt sett, en öppen dialogisk situation av kunskapsöverskridande där intresset för ämnet, 
inte en potentiell nytta, är förutsättningen för interaktionen. Det tredje exemplet är den intima relationen, till exempel kärleksförhållandet, där parterna själva, relationen mellan dem och deras delvis gemensamma handlingar är det egentliga målet. "I slike forhold", skriver Østerberg, "gjelder samkvemmet det å oppdage seg selv. Dette trer klart frem i kjærlighetsforhold. Ved å oppdage hva eller hvem den Andre er, oppdager jeg hva eller hvem jeg selv er" (1993e:196; jämför Østerberg 1977a:99-101). Han kallar detta för "det fortrolige åpne system" (1993e:197). Också här vore det svårt att tala om handlandets och olika handlingsalternativs "nytta" i någon rimlig mening.

Och därmed är vi framme vid Østerbergs egentliga ärende. Han konkluderar och frågar vidare:

Spillteoriens gyldighetsområde er begrenset, siden det er mange former for sosial interaksjon som ikke med rimelighet kan rekonstrueres som spill.

Men er det sikkert at alle spill kan fortolkes av matematisk spillteori? Jeg skal forsøke å vise at det ikke er slik, ved å gjennomdrøfte sjakkspillet som et sosialt interaksjonsforløp (1993e:197-198).

\section{Schackspelandets tre modus}

För att tydliggöra begränsningen med ett spelteoretiskt perspektiv på schack som social interaktion skiljer Østerberg på tre inställningar till (eller modus av) schackspelande: en brädesorienterad, en socialpsykologisk och en dialogorienterad. Som kommer att framgå, handlar det inte om olika stilar, så som man till exempel skiljer mellan aggressiva och mer försiktiga spelstilar, eller stilar kopplade till olika personer (Fine 1956; Gobet 2019:65-76; Puddephatt 2003:267-269) och historiska epoker (Opfermann 1982). Østerbergs uppdelning baseras i stället på vilket intentionalt föremål som schackspelaren förhåller sig till, alltså vad som står i fokus för dennes uppmärksamhet.

Den första inställningen, den brädesorienterade, kallar Østerberg också Steinitzaktig, efter Wilhelm Steinitz (1863-1900). Steinitz betraktas allmänt som den första världsmästaren i schack och som den förste moderne schackspelaren, då han efterhand kom att utveckla en delvis ny, systematiskt positionell, "vetenskaplig" spelstil som visade sig överlägsen den tidigare, mer djärva ("romantiska") stilen. Det Østerberg menar med Steinitz-modus är en inställning som är helt inriktad brädet och dess möjligheter och krav; det vackra, det rimliga, det lovande och så vidare. På en fråga om inte alla schackspelare måste besitta en förmåga att spela mot motståndarens "själ" svarade Steinitz att detta inte gällde för honom. Han koncentrerar sig, säger han, helt på brädet och tänker inte alls på motståndaren; denne kunde lika gärna vara "et abstrakt begrep eller en automat" (Østerberg 1993e:199; jämför Hannak 1991:34). ${ }^{1}$

1 Under 1800-talet turnerade med stor framgång en mycket sinnrikt konstruerad schackautomat, den spelande turken kallad, som i själva verket manövrerades av en dold, oftast framstående, schackspelare (se till exempel Strouhal 2000:60-67). 
Østerberg kallar därför denna inställning för solipsistisk; den andre, motståndaren, är visserligen nödvändig för spelet, men han eller hon påverkar det närmast från utsidan. I sig är därför inte motståndaren intressant; det gäller enbart att i varje läge finna det objektivt bästa draget, det drag som ställningen på brädet möjliggör eller kräver. Att vinna blir då heller inte nödvändigtvis allt. Man kan tänka sig spelare som faktiskt har möjligheten att välja vissa trygga drag som sannolikt skulle säkra det övertag som spelaren redan har, men som trots det spelar annorlunda. Ty att välja den blott trygga vägen vore ur ett strikt brädesorienterat perspektiv förkastligt, för om jag följer den, då svarar jag inte

på kravene fra sjakkbrettets logikk, jeg går ikke inn for å lage et godt parti, men nøyer meg med bare å vinne partiet. Det vil si: Ved å velge det trygge spill spiller jeg først og fremst for å vinne, ikke for å spille god sjakk (1993e:200). ${ }^{2}$

Brädet "vill” något annat och mer än att enbart kora en vinnare; i den mån en spelare verkligen fångas av brädet blir detta, vilket skall visas nedan, på sätt och vis en tredje part i spelet.

Den andra inställningen, den socialpsykologiska, kallar Østerberg också för Laskerartig efter Steinitz efterträdare som obestridd världsmästare under många år: Emanuel Lasker (1864-1941). Lasker byggde vidare på Steinitz arbete, men spelade samtidigt på ett delvis annat sätt än denne, ett sätt där kampen mot den andre står i centrum. Med denna inställning frågar man sig vad motståndaren har för plan eller strategi och man letar själv inte nödvändigtvis efter det "objektivt" sett bästa draget, utan efter det för motståndaren mest obehagliga. Den mycket inflytelserike schackförfattaren Richard Réti skrev helt frankt: "Lasker often deliberately plays badly" (Réti 2012:71). ${ }^{3}$ I själva verket finns det då i en given ställning inte enbart ett bästa drag, utan lika många "bästa drag" som det finns olika motståndare (Østerberg 1993e:202; jämför Hannak 1991:34-35). Då denna inställning, som i modern schacklitteratur ofta kallas

2 På frågan om han medvetet försöker skapa vackra partier svarar Grand Master (GM) Baadur Jobava: "Jag vill inte följa datoranalyser i $40 \mathrm{drag}$. I lagschack eller för landslaget har man för mycket ansvar och ska först och främst hämta hem poäng. Spelar jag individuellt dras jag åt det vackra. Det har kostat många poäng" ("Lång rockad. Badour Jobava" 2017:57). Det finns i flera turneringar också "skönhetspris", men det är ett något omtvistat fenomen. Den som verkligen försöker spela vackert lär ofta misslyckas. Och kanske är skönheten den illusio om vilken Pierre Bourdieu talade (jämför Bourdieu 2000:467-470), som döljer ett krassare spel, en delvis krassare verklighet?

3 Det finns en omfattande diskussion om huruvida Laskers spel skall betraktas som "psykologiskt" eller ej (Réti 2012; flera bidrag i Kotowski, Poldauf \& Wagner 2003). Kritiker av detta ganska etablerade synsätt menar att en sådan beskrivning är överdriven eller rentav oriktig och att den skymmer blicken för Laskers kunskap "om brädet" (Hooper \& Whyld 1984:179). En balanserad beskrivning ger enligt min mening Ulrich Krause (2001). Jag betraktar emellertid Østerbergs analys av spelmodus i stället för spelstil som mycket klargörande här och som det troligen riktiga svaret i denna kontrovers, en analys som kan göra båda sidor i diskussionen rättvisa. Märkvärdigt men intressant nog har Lasker också uppfattats som en spelteorins föregångare (Klaus 1965). 
för "praktisk schack", verkligen innebär, eller leder till, en kamp mellan (i normalfallet) två viljor och intellekt medför detta ofta känslor av skam, förödmjukelse och ånger; man kan helt enkelt bli överväldigad av den Andre (Østerberg 1993e:201, 204); en kamp där till och med själva livet kan tyckas stå på spel. Jämför följande skildring där en världsmästare beskriver en annan:

We were in the fifth hour. He was lost, ruined, not a chance! I knew it, he knew it. But he sat there - almost an hour! - calculating, calculating, calculating! Inside he was screaming. He was pale, like a dead man, but this force was going through him like millions of volts. I could feel it smashing and smashing at me across the board. Well, it had an effect, I can tell you that. Five or ten minutes - all right. But an hour! In the end, $I$ was the one screaming inside. When you play Bobby, it is not a question if you win or lose. It is a question if you survive (Boris Spasskij om Bobby Fischer, citerad efter Hoffman 2007:69-70). ${ }^{4}$

Østerberg diskuterar slutligen kort en tredje inställning, som han kallar dialogorienterad. Uppmärksamheten är här, liksom i den första, inriktad på brädet och dess positioner. Men här bortser man inte från den andre utan önskar dennes närvaro för att med hjälp av dennes bästa drag få syn på möjligheter som man inte såg eller kunde se på egen hand. Østerberg skriver:

Hvem av oss som vinner eller taper og hvorvidt partiet ender remis, er av underordnet betydning. Jeg spiller mot den Andre i stedet for mot meg selv, av samme grunn som jeg diskuterer en sak med andre i stedet for å ta standpunkt til den på egen hånd (1993e:204).

Den dialogorienterade inställningen handlar alltså om ett slags gemensam upptäckarglädje vid schackbordet. Østerberg lämnar den emellertid på det hela taget utanför analysen av spelteorins gränser, antagligen för att den inte alls, vilket ju spelteorin kräver eller förutsätter, förhåller sig till spelet som ett system med kalkylerbar nytta eller vinst; hur skulle man alls kunna göra upp en kalkyl om mål inte kan skiljas från medel, om glädjen i att spela schack inte kan uppnås på något annat sätt än genom att spela just schack?

Vad gäller de andra inställningarna och relationen dem emellan menar Østerberg apropå den Lasker-artiga, kamporienterade inställningens fokus på finter och knep följande:

4 Apropå döden: Desjarlais (2011:121-123) ger en intressant tolkning av den inte obligatoriska, men mycket vanliga försoningsritual som kallas post mortem, där spelarna i efterhand tillsammans går igenom och analyserar partiet med dess misstag och ospelade möjligheter. Jag föreställer mig att dessa post mortem-analyser mycket väl skulle kunna utgöra förebilden för den tredje spelinställning som Østerberg skildrar, den dialogorienterade. 
Selvsagt er slike knep en snylting på den sjakkbrettorienterte måten å spille sjakk på. Og mer alment forutsetter Lasker-måten Steinitz-måten, men ikke omvendt. For å spille som Lasker må man også forstå sjakkbrettets logikk, men hvis man kjenner sjakkbrettets logikk er det nok i seg selv. Steinitz-måten har forrang fremfor Lasker-måten (1993e:204).

\section{Østerbergs huvudargument}

Østerberg anser att verkligt schackspel oftast befinner sig i Steinitz-modus, att det alltså är brädesorienterat. Men ibland, skriver han,

foregår et skifte av intensjonal gjenstand: fra sjakkbrettet alene til sjakkbrettet og motstanderens oppfatning av sjakkbrettet. Og tilsvarende skjer et skifte av hensikt eller intensjon: Fra hensikten om å utforske sjakkbrettets muligheter og finne det beste trekket i stillingen, til hensikten om å forstå motstanderens sinn (eller psyke) og dra fordel av denne psykologiske kunnskap for å vinne partiet (1993e:207).

Detta innebär förstås en övergång till Lasker-modus. Och med denna övergång mellan olika modus är vi framme vid Østerbergs huvudargument: Det är visserligen, i princip, möjligt att lägga upp en strategi som alltid kan ge svar på frågan hur man bäst skall bemöta den andres drag. Det är också, i princip, möjligt att utveckla en motsvarande strategi med syfte att alltid spela det för motståndaren "ubehageligste trekket" (1993e:206). Men schack som social interaktion är så att säga summan, eller syntesen, av dessa modus (1993e:209). När spelteorin behandlar schack förbises enligt Østerberg denna dubbelhet:

Noe vesentlig mangler eller er utelatt, nemlig tvetydigheten som ligger i situasjonen, glidningen fra en modus til den andre, det fengslende ved sjakkbrettet som sådant, og av striden som sådan.

Denne tvetydigheten kan uttrykkes slik: Sjakk er ikke et dyadisk, men et triadisk forhold. Spillerne er ikke bare orientert henimot hverandre slik at de danner en dyade, men også henimot sjakkbrettet - en slags tertius som formidler mellom spillerne. Og de to modi - Steinitz-modus og Lasker-modus - betegner de to mulighetene: Innen sjakkbrettorienteringen er ikke motstanderen tesen for en uttrykkelig bevissthet, men en underforstått del av en situasjon. I den psykologiske modus er motstanderen stilt som gjenstand for bevisstheten, sammen med sjakkbrettet (1993e:207).

Och Østerberg menar alltså att just denna dubbelhet gör det olämpligt att analysera schackspelandet spelteoretiskt. Det är helt enkelt inte entydigt klart vad det är man gör när man spelar schack. Spelar man så att säga mot motståndaren eller mot brädet?

Och kanske är det så, det är min tolkning, att just denna schackspelandets tvetydig- 
het, som gör interaktionen vid brädet svår att fånga strikt spelteoretiskt, samtidigt gör det desto mer lämpligt som modell för att förstå social interaktion över huvud taget. Kanske är det så att mycken interaktion, särskilt den som har strategiska inslag, både är riktad mot den Andre och mot tertius (den "tredje"), och att interaktionen utan denna dubbelhet skulle bli platt eller intetsägande. Jag skall längre fram fördjupa denna tolkning något.

\section{Asplund om schack och socialpsykologi}

Asplunds schacktext utgör ett kapitel i en bok som även behandlar tankenöten som socialt och "kognitivt" fenomen samt artificiell intelligens. Genomgående kritiserar Asplund en inom kognitionsforskningen förekommande föreställning om tänkandet som en strikt intramental process inom en i kognitivt hänseende strikt en- eller avskild individ. Gentemot denna föreställning hävdar Asplund allt tänkandes sociala karaktär. Och som så ofta när det gäller Asplund (jämför Asplund 1987a) står det vetenskapliga experimentet, det faktiska eller det blott tänkta, i centrum för analysen.

Och hur förstår Asplund schack? Man kan lugnt säga att hans beskrivning av schack är tydligt interaktionistisk. Så menar han bland annat att schackspelandet, som vid en ytlig betraktelse skulle kunna uppfattas som summan av en serie åtskilda men i tiden på varandra följande drag vars betydelse bestäms "i huvudet” på respektive spelare, i själva verket består av drag som ej är skarpt avgränsade från varandra och vars betydelse därför bestäms av de motdrag de ger upphov till. Detta är säkert riktigt. Här vill jag dock tillägga att denna ömsesidiga bestämmelse inte kan vara fullständig eller kanske fullständig enbart under vissa omständigheter som ännu återstår att bestämma. Schackspelandet ställer nämligen inte bara krav på den egna förmågan utan också på motspelarens, något som blir tydligt i detta lätt vanmäktiga citat från en tidigare världsmästare:

Jag skulle ha varit lycklig över att ha fătt skapa alldeles ensam, utan att behöva koordinera min plan med motståndarens, för att åstadkomma något av värde. Ack, denne motståndare, denne påtvingade medarbetare! Varje gång skiljer sig hans föreställningar om det sköna från dina, och medlen (styrka, fantasi, teknik) visar sig så ofta otillräckliga för att aktivt främja dina avsikter! Hur många besvikelser vållar inte detta den sanne konstnären i schacket, som strävar inte bara efter att segra utan först och främst efter att skapa ett verk av bestående värde. Vilket lidande (okänt inom alla andra områden av konsten eller vetenskapen) är det inte att känna, att din tanke och fantasi i kraft av tingens egen ordning är obönhörligt fjättrade av en annans tanke och fantasi, som alltför ofta är medelmåttiga och alltid djupt skiljer sig från din (Aleksandr Alechin, citerad efter Gizycki 1961:117).

Kanske är detta exempel på att den sociala interaktionen alltid och av nödvändighet innebär ett risktagande? Jag är tämligen övertygad om att Asplund inte skulle ha invänt 
mot ett sådant påstående. När det gäller schack menar han dock att detta spel får sitt särdrag av att den ömsesidigt bestämmande turtagningen utspelar sig full öppet på ett bräde:

Låt oss införa begreppet "intermental scen”. Kanske är schackbrädet ett av de bästa eller mest renodlade exemplen på en dylik scen. Bägge spelarna har full överblick över brädet. Allt som sker, sker på brädet. Ingenting som sker utanför brädet hör till spelet (Asplund 2002:86-87).

Detta är också grunden till att man strängt taget inte kan fuska i schack. I romanen Sweet thursday förklarar Doc för den inbitne trixaren Joseph and Mary: "If it were possible to cheat there would be no game" (Steinbeck 1954:31). Han tillägger senare:
"Both players know exactly the same things. The game is played in the mind."
"I don't get it."
"Well, look! You can't cheat in mathematics or poetry or music because they're
based on truth. Untruth or cheating is just foreign, it has no place. You can't cheat in arithmetic" (1954:31; jämför Wide 2007).

När Asplund skriver att "[i]ngenting som sker utanför brädet hör till spelet”, och när Doc förklarar att man inte kan fuska i schack så måste nog ändå dessa påståenden kvalificeras. Den totala överblicken, denna spelets "renhet" om man så vill, kan nämligen inte förstås utifrån sig själv, utan köps alltid till priset av en "utsida”. Erving Goffman talar därför i sin analys av spel om rules of irrelevance som ett slags spelets relativt osynliga och i vart fall icke-artikulerade regler enligt vilka allt utanför spelet är irrelevant för spelet självt (Goffman 1961:19-26) och han skiljer också mellan game och gaming (Goffman 1961:36). Denna utsida (här förstådd som gaming) är i själva verket en arena för möjligt fusk och kring denna tycks till och med en egen avdelning i schacklitteraturen ha vuxit fram på temat det-är-visst-möjligt-att-fuskai-schack. ${ }^{5}$

Till möjligheten till en gemensam överblick fogar nu Asplund begreppet ett "allmänt schackförnuft" (2002:91-93; jämför också Fine 2015:26). Detta avser kunskapen om vilka drag som är de rätta att göra i en given situation. I den mån två spelare har eller tar del av detta allmänna schackförnuft, och gör det i lika hög grad (jämför citatet av Alechin ovan), så förstår de varandra - men inte nödvändigtvis brädet - fullständigt och varje drag kunde ha utförts av bägge spelarna. Enligt Asplund utgör detta allmänna

5 Jag skulle för övrigt tro att ett inslag av slump eller kontingens är en nödvändig förutsättning för möjligheten till fusk - i spel såväl som i vetenskap. Och i det vardagliga, goffmanska, livet tycks ett slags tvetydigt "fusk" vara en förutsättning för själva spelet. Intressant är att schack i den tidiga arabiska världen kunde tillåtas delvis just för att det ansågs sakna inslag av slump och dobbel (Shenk 2007:29-35). Ganska nyligen har en domstol i USA kommit till en liknande slutsats (Hallman 2003:105). 
schackförnuft den grund mot vilken innovativa drag sedan kan utföras; det nydanande draget blir bara begripligt mot fonden av gemensam (allmän) schackkunskap.

Jag tror att en av de saker, och kanske den viktigaste, som Asplund vill understryka i sin behandling av schack är att schack inte är något man kan spela på egen hand (jämför Zweig 1974). Det låter förstås först som en trivialitet, men Asplund menar att själva spelandet är en djupast sett ömsesidig sysselsättning som inte kan förstås om man tänker sig att två helt skilda (avskilda) spelare enbart har råkat komma samman över ett parti schack, där alltså den ene spelarens drag och motdrag, strategi och förståelse av partiets möjligheter och de egna planerna och möjligheterna enbart råkar i tid och rum sammanfalla med den andres. Också den ensamme spelaren spelar tillsammans; han eller hon tar den andres perspektiv på sig själv när dragen utförs eller analyseras. Den andre är på så sätt alltid redan en del av oss (jämför Mead 1967:152-164).

\section{Asplund om Østerbergs underligheter}

Asplund vill emellertid inte bara beskriva schackspelandet som ett exempel på vårt sociala tänkande och som ett led i kritiken av en viss "kognitivistisk" förståelse av tänkande och problemlösning. Han inleder nämligen sitt kapitel om schack med en ganska skarp kritik av Østerbergs ovan behandlade schackanalys, och vi skall nu i vår tur granska denna kritik.

Efter att kortfattat ha återgivit Østerbergs analys av schackspelandets olika modus skriver Asplund:

Denna indelning i ett solipsistiskt, ett socialpsykologiskt och ett dialogorienterat modus är underlig. Varför skulle Steinitz "realism" göra honom till solipsist? Varför skulle Laskers list utgöra en speciellt socialpsykologisk kvalitet? Och varför skulle ett icke-kompetitivt spelsätt vara mer dialogorienterat än ett kompetitivt?

Det allra underligaste är att Østerberg utnämner det solipsistiska spelsättet till det primära spelsättet (2002:83-84).

Om detta finns en del att säga. Tar vi den första frågan, den om Steinitz realism, så rör det sig nog om ett rent missförstånd. Østerberg skrev följande om det brädesorienterade spelsättet och dess koppling till Steinitz:

Denne spillemodus kan forbindes med navnet til tsjekkeren Wilhelm Steinitz (1836-1900), som var verdens beste spiller i 28 år, og som etter den "romantiske" tidsalderen til Anderssen, Labourdonnais og Morphy innledet en "realistisk" stil (1993e:199).

Det är som vi sett riktigt att Østerberg förbinder den brädesorienterade inställningen, åtminstone i dess ytterlighet, med ett slags solipsism. Men detta har just inget eller 
mycket litet med realism att göra. ${ }^{6}$ Och här lurar ytterligare ett missförstånd, ett som framkommer tydligt i Asplunds andra fråga. Det förefaller mig som om Asplund inte fullt ut har gjort klart för sig vad Østerberg menar med den brädesorienterade inställningen och därför inte heller kan gå med på att kalla den andra inställningen, modus à la Lasker, för socialpsykologisk. Det verkar nästan som om Asplund vill underkänna

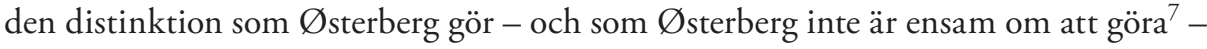
för att, om man så vill, i stället betrakta allt schackspelande som socialpsykologiskt. För om man går från en situation där man fokuserar på brädet till en situation där plötsligt motståndaren som motståndare utgör centrum för ens uppmärksamhet, varför skulle det då vara "underligt" att kalla denna senare situation socialpsykologisk? Kanske kunde man kalla den något annat, och något bättre. Men inte behöver man tycka att termen socialpsykologisk i detta fall är underlig? ${ }^{8}$

Och nu till Asplunds tredje fråga: "[V]arför skulle ett icke-kompetitivt spelsätt vara mer dialogorienterat än ett kompetitivt?”. Den frågan beror ju naturligtvis på hur man förstår begreppet "dialog”. Vad gäller Østerberg har denne dock, menar jag, i sin inledning gjort tämligen klart hur han tänker sig en dialog. Dialogen är, som vi sett, för honom "et åpent system":

Her forsøker enhver å overskride sin egen forståelse av emnet ved å svare på den Andres forsøk på å overskride sin. Den gjensidige utveksling er strengt tatt ikke det samme som gjensidig å gi og å ta. For det som utveksles (såsom tanker) er ikke noe som kan gis eller tas, og ikke måles. [---] Det åpne dialogiske systemet gjelder

6 Steinitz "realism" har beskrivits på följande sätt: "[Tidigare] härskade den åsikten, att segern skulle vinnas genom genialitet. [...] Steinitz bryter nu föreställningen om kraften i den kombinatoriska uppfinningsrikedomen och ingår i skarp polemik mot det historiska förhärligandet av kombinationsspelet. Framgångsrika och korrekta kombinationer, som bryter även det starkaste försvar, betraktar han inte längre som en följd av subjektiva egenskaper hos den kombinerande, utan som en följd av spelets tidigare förlopp. Förutsättningarna för kombinationen hade framkommit i huvudsak genom succesivt anhopande av positionella fördelar. Denna Steinitz' uppfattning betecknar ett stort framsteg, och det är inget tvivel om, att den är en skapelse av en realistisk och naturvetenskapligt skolad ande" (Hörberg \& Westberg 1961:10-11; jämför Holländer 2003). Entzauberung des Schachs? Schackets avförtrollning? Säkert hade i alla fall schackets utveckling kunnat utgöra ett fint exempel för Max Weber när han skildrade den västerländska kulturens tilltagande (mål/medel-) rationalisering. Lägg därtill Laskers kampmoment och Weber skulle väl känna sig "hemma"! År 1922 skrev Réti (2002:55-56): "The age of heroes is over in chess, as well as in other things."

7 Jämför Desjarlais (2011:66). Østerberg bygger sin analys åtminstone delvis på framställningen i Jacques Hannaks biografi (1991), men han kopplar dennes distinktion - "Playing the man or the board?" - till Edmund Husserls begrepp intentionalt föremål och analyserar dessutom relationen mellan dessa två modus. Jag är övertygad om att Østerberg också har den norske filosofen Hans Skjervheims begreppspar deltagare och åskådare (Skjervheim 1960; jämför Wide 2017) i åtanke och att hans analys faktiskt tillför en ny dimension till denna berömda distinktion (se de avslutande kommentarerna nedan).

8 Det hör till saken att Asplund i detta sammanhang använder ordet "underlig" i en kvalificerad bemärkelse, närmast betydande "mycket underlig", "vid sidan av" eller rent av "felaktig". 
et felles emne som stadig vedlikeholdes ved vår dialog. Vår oppriktige opptatthet av selve emnet (snarere enn et sterkt ønske om å "vinne” diskusjonen) er en forutsetning for interaksjonen. På nytt faller betraktninger om hensiktsmessighet utenfor rammen (1993e:196-197).

Østerberg är alltså på det klara med att man kan samtala också på ett annat sätt, nämligen med syftet att "vinna" diskussionen eller med något slags "nytta" i åtanke, men han räknar inte in detta slags samtal under rubriken "öppen" dialog. Häri följer Østerberg en i sociologin ingalunda okänd uppdelning mellan strategiskt och kommunikativt handlande (jämför Habermas 1987).

Så till det som Asplund anser vara allra underligast, att Østerberg menar att den brädesorienterade inställningen är primär i förhållande till den socialpsykologiska. Och här finns det också en retorisk märklighet. Asplund skriver, som vi sett, att Østerberg "utnämner" den brädesorienterade inställningen till den primära. Detta är inte korrekt. Visserligen kunde man väl i detta fall som i de flesta andra önskat sig en mer utförlig analys. Men Østerberg argumenterar för sin sak. För den som följer Østerbergs tankegång står det ju klart att brädesorienteringen är en förutsättning för andra inställningar, eftersom brädet i allt schackspel måste förstås och tas med i beräkningen. Först när man har en någorlunda klar bild av ställningen på brädet kan man börja tänka på olika planer och strategier i förhållande till motståndaren såsom en särskild person som skall besegras.

Faktiskt borde Asplund ha kunnat finna en hel del stöd för sin argumentation hos Østerberg. De är inte ute i exakt samma ärende, men det finns stora överlappningar mellan den spelteoretiska ansats som Østerberg diskuterar och den kognitiva modell som Asplund kritiserar. Om man emellertid läser Østerbergs och Asplunds texter efter varandra så slås man av ett märkligt faktum. Asplund återger inte Østerbergs huvudproblem och det tycks heller inte som om han verkligen har förstått det. Hur kan det komma sig?

\section{Varför förstår inte Asplund Østerberg?}

Vid försöket att besvara denna fråga framträder en första påfallande skillnad mellan Østerbergs och Asplunds texter: den förre utgår i huvudsak från schackmästare och deras syn på schack och diskuterar och analyserar ett verkligt parti mellan två mästare, den senare tycks behandla schack snarare utifrån ett amatör- eller vardagsperspektiv. Om Asplunds erfarenheter vid brädet vet jag inget, men Østerberg var mycket kunnig i schack (han var en tid norsk ungdomsmästare). ${ }^{9} \mathrm{Nu}$ finns det ju inget som säger att

9 Schackskribenten och International Master (IM) Atle Grønn (2017) skrev efter Østerbergs död en kort nekrolog på temat Østerberg som schackspelare. Se också den intervju i vilken Østerberg beskriver sitt eget schackspelande och betonar det erotiska, det estetiska och det materiella i spelet, liksom brädesorienteringen (Andersson 1983:60-63), samt den korta biografiska skissen i Sven Sundbøs bibliografi (1999). En ögonblicksbild av Østerberg som schackspelare i mogen ålder har givits av Nils Christie och Hedda Giertsen (2008:191-192). Østerbergs första publikationer var för övrigt schackanalyser (Sundbø 1999:1). 
"mästarschack" självklart skulle vara mer riktig schack än amatör- eller vardagsschack. Men kanske kan man ändå se det så, att Østerberg mer än Asplund beskriver ett inifrånperspektiv på schack och schackspelande? Jag kan inte undgå tanken att Asplund, mer än Østerberg alltså, ser schacket som ett exempel på en typ av social interaktion, ett exempel som på grund av sin struktur tydligt uppvisar vissa mer allmänna interaktionistiska drag. Detta skulle då också kunna utgöra ett hinder för förståelsen, eftersom det så att säga skulle, i viss utsträckning, låsa Asplund vid den uppfattning som han redan har. Jag vill här anföra följande som ett exempel på detta: $\mathrm{Om}$ nu, som Asplund hävdar, tänkandet utvecklas gemensamt på brädet, så skiljer sig dock detta tänkande från tänkandet i en vardaglig interaktion eller i ett vardagligt samtal. ${ }^{10} \mathrm{Ty}$ schacktänkandet är mycket mer tydligt uppdelat; den som inte är vid draget är så att säga dömd till ett slags passivitet och kan inte komma med några som helst inspel, vinkar och så vidare, den är helt enkelt inte med. Enligt psykoanalytikern och Grand Master (GM) Reuben Fine ägnar sig många i det läget åt att dagdrömma:

During this period one might expect him to study the position. That happens rarely. Most of the time he daydreams, and his daydreams follow the usual course which have nothing to do with chess. At the same time the tension persists because he never knows when he will be called back to make a move (Fine 1956:22-23).

Och den som är vid draget kan därför inte, återigen i motsats till den vardagliga interaktionen, vänta sig något "extra" inlägg från den andre, eller vänta på, eller låtsas vänta på, vinkar etcetera. Detta samtidigt som varje drag är betydelsefullt! Journalisten J.C. Hallman, som tillbringat mycken tid i schackets värld, har gjort följande iakttagelse:

I was stuck by the fact that players in tournament games were frequently not at their boards - once the games had moved sufficiently into their openings, many players made their move, hit their clock, and left. [...] The opponent, who might also have left, then returned, moved, and left again, so that in some games it was entirely rare for the players to sit face-to-face. It was as though every move was a period of intensity, like holding your breath underwater, and afterward the player would swim to the surface to recover (2003:222-223).

Det hade varit intressant att jämföra denna schackspelets sociala andhållning med Asplunds begrepp social responsivitet (Asplund 1987a). Snarare än som en böljande ström framstår nu spelet som ett ständigt fram och stopp, där stoppen - eller är det framåt? - innebär att man så att säga slängs in spelet och sedan lika plötsligt slängs ut. Och denna interaktionens uppstyckning, som också medger kortare eller längre gemensamma uppehåll i spelet (jämför Wendling 1996:92), detta som vi kunde kalla absoluta turtagande, återspeglas i spelets notation. Nu menar Asplund att notationen, alltså det protokoll där dragen i ett

10 Apropå samtal: enligt en viss schackpedagogisk tradition skall man samtala, inte med motståndaren, utan ... med pjäserna (Hall 2001:43)! 
parti förtecknas - denna för schacket helt egna form av litteratur (Fine 2015:126) - inte gör spelets flytande karaktär rättvisa (Asplund 2002:85). Det ligger en hel del i detta, och det finns i litteraturen fina exempel på i synnerhet blixtschack som en form av gemensam improvisation (Hallman 2003:316-318). Men frågan är om inte Asplunds bestämda uppfattning av den sociala interaktionen hindrar honom från att uppfatta vissa för schacket och schackspelandet karaktäristiska drag (jämför också citatet av Spasskij ovan).

Till detta kan kopplas en oklarhet rörande ett par av själva nyckeltermerna. Jag tänker återigen på begreppen "solipsism" och "socialpsykologi". Med tanke på att Asplunds bok i dess helhet kan förstås som en socialpsykologisk kritik av föreställningen om ett i grund och botten en- och avskilt tänkande som antas försiggå inuti huvudet på en- och avskilda människor, så vore det kanske inte så underligt om han reagerade på Østerbergs beskrivning av en "solipsistisk" inställning som varande mer grundläggande än en "socialpsykologisk". Och kanske har verkligen dessa ord ställt till det så pass mycket att Asplund inte lyckas förstå vad Østerberg menar? Ty den som läser Østerbergs text noga borde ju annars lägga märke till, att han skriver att den brädesorienterade inställningen $i$ sin ytterlighetsform (1993b:199) blir en form av solipsism, alltså att spelaren agerar som om den andre inte vore där. Men detta betyder ju inte att spelarens tänkande är strängt solipsistiskt. För Østerberg är den konsekventa solipsismen en ohållbar position, men det hindrar inte att vi kan agera solipsistiskt alltså i ond tro förneka existensen av den andre (se till exempel Østerberg 1977a:72-88; 1977b:33; 1993d:47-61). Och socialpsykologi? Ja, det är nog tydligt att Østerberg använder detta ord för att beskriva just den dimension i vilken den konkreta kampen mellan två motståndare utspelar sig. Kanske har denna begränsning av ordets räckvidd i Østerbergs text spelat en viss och olycklig roll i detta sammanhang?

Jag skulle vilja försöka mig på följande tolkning. Jag tror, hur paradoxalt det än kan låta, att Asplund själv i sin beskrivning av schack aldrig lämnar det som Østerberg kallar den brädesorienterade, "solipsistiska" inställningen (utan, naturligtvis, att för den skull vara solipsist i ordets strängaste bemärkelse). Schack blir i hans behandling till ett exempel på socialt tänkande och handlande på en grundläggande nivå, och schacket framstår då som ett problem, ett slags tankenöt. Hur löser man denna nöt? Till skillnad från hur det är med vanliga tankenötter (vars sociala struktur och dramaturgi Asplund också analyserat) finns här - utom i schackproblemens särskilda avdelning - ingen enkel lösning som spelarna skall försöka komma på. Därför tar analysen ett annat spår, hän mot distinktionen mellan det allmänna förnuftet och det överskridande draget. Men också här blir analysen präglad av föreställningen om ett problem, något som liknar ett socialpsykologiskt experiment. Och denna gång är Asplund inte, som mången gång förr, den listige kommentatorn (jämför Asplund 1987a, 1991), utan snarare experimentatorn själv. Just hans iver att visa socialpsykologins elementära betydelse, eller de socialpsykologiska dimensionerna på de mest elementära nivåerna av undersökningar av människans liv, gör att han, föreställer jag mig, tror sig ha den rätta lösningen inom räckhåll och att det är den spelarna och vi läsare skall förstå, komma på eller få berättad för oss. Hade han inte förhållit sig som en åskådande experimentator i ett relativt abstrakt schackexperiment, hade det nog varit 
lättare för honom att förstå skillnaden mellan det Østerberg kallar brädesorienterad och socialpsykologisk inställning, och rörelsen mellan dessa. Med andra ord: den som ser socialpsykologi överallt riskerar att göra sig blind för distinktioner som icke desto mindre är socialpsykologiskt intressanta. Det kanske är för mycket sagt, men möjligen kunde man argumentera för att Asplunds teori om social responsivitet själv har drag av den abstrakta socialitet som den också behandlar (jämför Eriksson 2005)?

\section{Schackbrädet som tertius}

De återgivna sociologiska analyserna av schack har lyft fram brädets betydelse. Asplund talar som vi sett om brädet som en intermental scen, ett begrepp besläktat med hans mer kända begrepp responsorium (Asplund 1987a:52-53; 1987b) och även med ett mer allmänt sociologiskt scenbegrepp. På den intermentala scenen är dock allt öppet. Det finns inget bakom, det finns inga hemligheter; all kunskap är delad. $\mathrm{Nu}$ kan detta tyckas vara ett märkligt begrepp, så till vida som till exempel Goffmans användning av scenbegreppet tvärtom implicerar hemligheter, uppträdanden, finter och knep, taktfullhet och så vidare (se till exempel Goffman 1990). Men jag tror att man skall förstå Asplund som att han faktiskt beskriver det sociala tänkandets scen - och tanken känner inga hemligheter! Det vore i så fall lätt att föreställa sig att schackets tydliga, enkla och obändiga regler, som i officiella sammanhang kallas lagar (Hooper \& Whyld 1984:181), förmår upprätta ett slags öppen arena för gemensam problemlösning. De strängaste regler borgar för den största öppenhet. De skulle i så fall bli till ett slags oantastliga hypoteser eller axiom som säkrar en objektiv behandling av ämnet. Men hur är det egentligen med denna öppenhet i just schack? Hur är det med det allmänna schackförnuftet? Jag tror som sagt att Asplunds analyser av tankenötter och socialpsykologiska experiment kan ha förlett honom på denna punkt, så att han snarare behandlar schackproblem än schack. Ty visst är schacket ett slags gåta, men ingen, inte ens de starkaste datorprogrammen, sitter ju inne med dess lösning. Det allmänna schackförnuftet summerar de lärdomar som schackmästare, nuförtiden ofta med hjälp av datorer, skaffat sig och schackvärlden, men dessa lärdomar är pragmatiska och föga heltäckande. Det allmänna schackförnuftet är inte så allmänt, det är snarare delvis lokalt än helt globalt (jämför Leifer 1988). ${ }^{11}$ Och detta förändrar spelets villkor.

11 Eric Leifer (1988:501-504) för i en intressant analys fram den uppfattningen att det som skiljer framstående schackspelare från amatörer är, om jag har förstått honom rätt, att de förra har förmågan att starta (och uppfatta) och spela lokala spel med delvis, men inte helt, andra mål än de som gäller för ett parti i dess helhet. När det gäller schackdatorerna och -programmen tror jag att det är rimligt att tänka sig att de i detta sammanhang inte spelar rollen av en artificiell Andre, utan snarare innebär en utvidgning av brädet. Man kan förvisso använda sig av datorer och program för att analysera och för att öva sig. Men man spelar inte mot dem i egentlig mening, snarare spelar man mot dess konstruktörer och programmerare (jämför Bloomfield \& Vurdubakis 2008; Kasparov 2018). Jag tror att på ett liknande sätt måste Asplunds allmänna schackförnuft till slut betraktas som en del av brädet, snarare än ett som ett redskap att utforska eller bemästra det med. Denna analys antyder alltså att tertius gränser är flytande. 
Eftersom kunskapen om brädet, om schackspelet, är begränsad blir det plötsligt möjligt att spela med och mot den andres, och ens egna, begränsade kunskap, att vara socialpsykolog à la Lasker. Om man skulle tala med meadska begrepp kunde man säga att spelarna kan spela just precis eftersom de inte fullt ut internaliserat den generaliserade andre (det allmänna schackförnuftet). Och den andra sidan av detta (jämför Mead 1967:152-164) är att spelarna inte har erhållit fullt stabila speljag; de är i detta sammanhang inte de fullt ut och rakt igenom rationella aktörer som spelteorin förutsätter och behandlar. Schackbrädet som tertius tycks upprätthålla denna otydlighet där ego inte enbart står mot alter, utan där interaktionens tredje hela tiden så att säga lägger sig i och påverkar aktörerna och interaktionen. Jag menar därför att begreppet intermental scen bör kompletteras med idén om brädet som tertius. Jag tror att schackspelande inte fullt ut kan förstås om man inte ser det som ett spelande så att säga både med motståndaren mot brädet och med brädet mot motståndaren och jag menar att styrkan i begreppet tertius ligger i att det förmår fånga just denna dubbelhet.

\section{Avslutande kommentarer om tertius, spel och sociologi}

Har världen utanför brädets 64 rutor något att lära av diskussionen ovan? Jag menar att den mycket väl skulle kunna ha det, och jag skall avslutningsvis kort argumentera för den uppfattningen genom att först relatera begreppet tertius till olika perspektiv på och teorier om spel, och sedan diskutera huruvida tertius också skulle kunna tänkas vara ett bidrag till den mer allmänna sociologiska vokabulären, en vokabulär där ju spelmetaforer ingalunda är ovanliga.

När det gäller litteraturen om spel och spelande kan man göra en grov uppdelning mellan å ena sidan spelteoretiska ansatser (se till exempel Swedberg 2001) och å andra sidan studiet av "konventionella" spel som dessa faktiskt utövas i olika samhällen (se till exempel Henricks 2015). Om vi först ser till spelteorin, så är det faktiskt inte helt klart om denna verkligen behandlar spel och spelande i ordens vanliga betydelse. Richard Swedberg menar till exempel att "[ $\mathrm{t}$ ] here exists no necessary logical connection between game theory and ordinary games" (2001:302) och att "'[i]nteractive decision theory' may describe what game theory is about more accurately than what its conventional name does" (2001:302; jämför Hegselmann 1995). Varför är det så? Ett möjligt svar har givits av Eric Leifer: "Game theory seeks solutions that would eliminate the need to actually play games and hence cannot explain why some games are played out, often with skills that are widely admired and emulated" (1988:499). Det som här saknas, sett ur det mer "konventionella" spelandets perspektiv, är alltså ett begrepp om spelets och spelvärldens egenart (jämför Huizinga 2001; Fink 1957; Henricks 2015), det som så att säga är själva poängen med spelet. ${ }^{12}$ När Immanuel Kant vid ett tillfälle beskrev

12 Men naturligtvis är det, sociologiskt sett, möjligt att uppfatta spelteorin själv (liksom andra teorier) som ett spel i ordets vanliga betydelse. En sådan uppfattning innebär inte nödvändigtvis ett förklenande av verksamheten i fråga (jämför Huizinga 2001:161-173; se också diskussionen nedan). 
olika typer av handlande bestämde han spel (das Spiel) kort och gott som en "en sysselsättning som är angenäm i sig”. Och han la till att "bara så [alltså som angenäm i sig] kan den utfalla på ett ändamålsenligt sätt (det vill säga lyckas)" (Kant 2003:163). Detta går naturligtvis på tvärs med den spelteoretiska förståelsen av spel, där vinsten så att säga är allt. Med tanke på teorins syfte och struktur förefaller det mig därför inte troligt att begreppet tertius skulle vara till någon större glädje för spelteorin, annat än som ett hjälpmedet att bestämma teorins gränser i förhållande till vissa typer av social interaktion (se avsnitten om Østerberg ovan).

Om spelteorin och dess bestämning av spel är möjliga att formellt definiera (se till exempel Hegselmann 1995), är detta desto svårare när det gäller mer allmänna teorier om spel och spelande så som orden förstås i vardagligt språkbruk. Wittgenstein menade, och helt säkert med visst fog, att man "kan säga att begreppet 'spel' är ett begrepp med suddiga kanter" (Wittgenstein 1978: \$ 71); det är helt enkelt en del av det naturliga språket och som sådan undflyr det försöken till formella definitioner. Så vad ska man göra? Thomas S. Henricks skriver att de flesta som arbetat teoretiskt med spel (och lek - dessa begrepp skiljer sig på många språk inte lika tydligt åt som på de skandinaviska språken) helt enkelt "are inclined less to offer a strict definition of their subject than they are to provide a list of essential qualities, characteristics, or traits" (Henricks 2015:34; jämför Sutton-Smith 1997). Henricks går igenom många sådana listor och försöker sedan bestämma spel/lek som en form av "meaning construction and self expression" (2015:42). Till sin hjälp ritar han upp en mångrutad korstabell som betonar följande aspekter: play as action, play as interaction, play as activity, play as disposition, play as experience och play as context, där dessa "play as ...", i sin tur har underavdelningar och jämförs med eller bestäms i realtion till andra typer av handlingar eller fenomen, nämligen work, communitas och ritual. Till yttermera visso diskuterar han sedan dessutom kombinationer av dessa handlingar och fenomen (2015:63). Slående är emellertid att varken denna mycket ambitiösa och systematiska beskrivning, eller de andra teorier som han redogör för lägger någon särskild vikt vid det som jag efter Østerberg kallar tertius, alltså vid den formella interaktiva strukturen hos spelredskap (Spielzeuge, playthings). En sådan diskussion saknas också i det relativt nyutgivna och ganska omfattande verket The handbook of the study of play (Johnson, Eberle, Hericks \& Kuschner 2015). Nå, men är detta verkligen en fråga om en brist, ett problem? Jag tror faktiskt det. Många som skrivit om spel (och lek) har betonat både att spelet i någon mån befinner sig i en värld "bredvid" den vanliga, verkliga världen, att spelandet på ett avgörande sätt är socialt och att spelet har en egen kraft som visserligen inte verkar oberoende av vår egen inställning, men som icke desto mindre förmår dra oss in i spelet (till exempel Fink 1957; Huizinga 2001; Henricks 2015). Jag tänker mig nu att begreppet tertius, som på en och samma gång kan fånga ett väsensdrag hos åtminstone en grupp av spel och vara öppet för, ja rent av uppmuntra, konkreta undersökningar av särskilda spel, kan bidra till att förklara spelredskapens betydelse för dessa aspekter och sammanhanget mellan dem. Jag tror vidare att begreppet skulle kunna bidra till förståelsen av varför och hur olika typer av spel, konventionella och även mer metaforiska, utvecklas, tillbakabildas, inte utvecklas, 
fortlever och så vidare, hur, med andra ord, spelandet förhåller sig till icke-spelande. Och att på detta sätt addera ett begrepp till litteraturen om spel tycks desto enklare, som denna, åtminstone i sin nuvarande skepnad, inte utgör ett system av entydigt bestämda eller sammanlänkade begrepp.

Om begreppet tertius potentiella betydelse för sociologin i allmänhet tror jag att man kan tänka på åtminstone två sätt. För det första finns det i sociologin (och mer allmänt i samhällsvetenskapen) många författare som använt sig av spelmetaforer av olika slag (jämför Henricks 2006), och som har utvecklat begrepp för att beskriva till exempel att och hur social interaktion ofta eller alltid utspelar sig på eller bakom en scen (Goffman 1990), i ett responsorium (Asplund 1987a, 1987b), inom en eller annan mer eller mindre instabil ram (Goffman 1974), på ett eller annat fält (Bourdieu 2000; jämför Swedberg 2001:333, n. 71) och så vidare. Dessa och liknande begrepp är allmänt erkända som mycket viktiga och de fokuserar på sådana aspekter som interaktionens/spelandets dramaturgiska, institutionella, och symboliska ramar eller villkor, på dess kontext $\mathrm{i}$ vid bemärkelse. Tertius borde nu kunna utgöra ett komplement till dessa begrepp eller berika dessa och liknande perspektiv då det, i bästa fall, kan belysa vad som faktiskt är "fun in games" (Goffman 1961), liksom faktiskt något av kraften i spelets eller fältets illusio (Bourdieu 2000; jämför vad gäller begreppet illusio också Huizinga 2001:20). Därigenom skulle begreppet kunna bidra till förståelsen av varför vissa områden i det sociala livet men inte andra tycks utgöra lämpade grogrunder för nya spel och så vidare. Analyserna skulle i bästa fall kunna stimulera till undersökningar om vilka spel vi faktiskt spelar i vårt samhälle och hur vi spelar dem, och rent av vilka spel vi vill spela. Och tack vare den dubbelhet som begreppet tertius fångar, skulle de kunna göra det utan att hemfalla åt frestelsen att tolka spelandet som en medvetet eller omedvetet fullt ut cynisk verksamhet ("spelet handlar egentligen blott om ...").

För det andra bör tertius kunna berika den rent allmänna förståelsen av social handling och interaktion. Jag vill belysa detta genom att knyta an till Habermas välbekanta distinktion mellan strategiskt och kommunikativt handlande (Habermas 1987). Det strategiska handlandet är målorienterat och det råder här ingen nödvändig principiell kognitiv jämställdhet mellan ego och alter. Det kommunikativa handlandet är däremot inriktat mot samförstånd och på handlingskoordinering på grundval av gemensamt insedda skäl och sakförhållanden (faktiska, normativa och expressiva). Denna uppdelning, så som den formulerades i Theorie des kommunikativen Handelns, är mycket tydlig, för att inte säga skarp (även om Habermas senare har försökt nyansera den; se till exempel Eriksen \& Weigård 2000:60-67); för den som handlar kommunikativt är erkännandet av alters implicita och explicita giltighetsanspråk helt avgörande, för den som handlar strategiskt är de av underordnad betydelse (skärpan i fråga är för övrigt besläktad med skärpan i andra liknande och besläktade distinktioner, se till exempel Skjervheim 1960; jämför Wide 2017). Men tänk nu på det vetenskapliga seminariet (jämför Habermas 1987:411-412). Det vore förstås ett mycket dysfunktionellt seminarium, vetenskapligt sett, om deltagarna i huvudsak agerade strategiskt (strängt resultatorienterat) för att uppnå sina egna mål; på något sätt måste ju ämnet och dess möjliga sanning stå i centrum (jämför Østerbergs diskussion av det kollegiala 
samtalet ovan). Men handlar deltagarna för den skull rent kommunikativt? Förvisso, vid seminariet bör alla vara formellt jämställda - här bör den ideala talsituationen råda (Habermas 1989:174-183). Och ändå vet nog varje person som deltagit vid ett seminarium att det ofta eller åtminstone ibland, och ofta när seminariet fungerar väl rent vetenskapligt, uppstår ett slags lustfylld kamp - ett slags spel! - mellan deltagarna eller några av dem (jämför Huizinga 2001:161-173; Russell \& Ryall 2015:143). Själva ämnet blir då, föreställer jag mig, interaktionens tertius, och ego och alter kämpar, försåvitt seminariet inte urartar till ren maktkamp, så att säga både med varandra för att bättre förstå "saken" och med saken mot varandra och varandras tolkningar, varandras sätt att ställa frågor, varandras metoder och så vidare. Man spelar här alltså både mot och med varandras relativa okunskap, och man spelar samtidigt, och just därför, så att säga med och mot ämnet. Och det förefaller mig nu som om detta spel, i en eller annan form, är nödvändigt för vetenskapen. För vetenskap handlar ju till syvende och sist inte enbart om att finna pålitliga svar eller lösningar på vissa redan givna frågor eller problem (om den, som Charles Sanders Peirce skrev (1992:139), "opinion which is fated to be ultimately agreed to by all who investigate"), utan också om att finna de rätta frågorna och problemen. Och arbetet med att finna dessa frågor tycks mig inte fullt ut kunna analyseras i termer av antingen strategiskt eller kommunikativt handlande, eller ens av en blandform av dessa (jämför Eriksen \& Weigård 2000:60-67). Här borde nog en tredje handlingstyp, en som kretsar kring tertius kunna vara klargörande.

Detta arbete har behandlat schack, sociala interaktion och, i viss utsträckning, strategiskt handlande, och det har gjort det i synnerhet utifrån Dag Østerbergs och Johan Asplunds perspektiv. Det är min förhoppning att behandlingen därvid i någon mån bidragit till en fördjupad förståelse av dessa fenomen och perspektiv. Jag hoppas emellertid också att arbetet har lyckats antyda att och på vilket sätt begreppet tertius skulle kunna vara ett tillskott till det allmänna sociologiska språket. Begreppets fulla betydelse och värde återstår dock ännu att bestämma.

\section{Referenser}

Andersson, S. (1983) Resgods. Samtal med nordiska sambällsvetare. Göteborg: Korpen. Asplund, J. (1987a) Det sociala livets elementära former. Göteborg: Korpen.

Asplund, J. (1987b) Om hälsningsceremonier, mikromakt och asocial pratsamhet. Göteborg: Korpen.

Asplund, J. (1991) Essä om Gemeinschaft och Gesellschaft. Göteborg: Korpen.

Asplund, J. (2002) Genom huvudet. Problemlösningens socialpsykologi. Göteborg: Korpen.

Aycock, A. (1990) "Play without players, players without play. The world computer chess championship", Play \& Culture 3 (2):133-145.

Aycock, A. (1992) "Finite reason. A construction of desparate play", Play \& Culture 5 (2):182-208.

Bernard, J. (2003) "Un ensemble né d'une pratique ludique. Les joueurs d'échecs professionnels", Socio-anthropologie 13. https://doi.org/10.4000/socio-anthropologie.175 
Bloomfield, B.P. \& T. Vurdubakis (2008) "IBM's chess players. On AI and its supplements", The Information Society 24 (2):69-82.

https://doi.org/10.1080/01972240701883922

Bourdieu, P. (2000[1992]) Konstens regler. Det litterära fältets uppkomst och struktur. Stockholm: Symposion.

Christie, N. \& H. Giertsen (2008) "På reise med Dag", 185-193 i H. Nilsen (red.) Frihet og klasse. Tekster til Dag Østerberg. Oslo: Res Publica.

Cockburn, A. (1975) Idle passion. Chess and the dance of death. London: Weidenfeld $\&$ Nicolson.

Desjarlais, R.R. (2011) Counterplay. An anthropologist at the chessboard. Berkeley: University of California Press.

Eales, R. (1985) Chess. The history of a game. London: Batsford.

Ensmenger, N. (2012) "Is chess the drosophila of artificial intelligence? A social history of an algorithm", Social Studies of Science 42 (1):5-30. https://doi.org/10.1177/0306312711424596

Eriksson, B. (2005) ”Johan Asplund. Ideas and position”, Acta Sociologica 48 (4):284291. https://doi.org/10.1177/0001699305059959

Eriksen, E.O. \& J. Weigård (2000[1999]). Habermas politiska teori. Lund: Studentlitteratur.

Fine, G.A. (2015) Players and pawns. How chess builds community and culture. Chicago: University of Chicago Press. https://doi.org/10.7208/chicago/9780226265032.001.0001

Fine, R. (1956) "Psychoanalytic observations on chess and chess masters", Psychoanalysis. Journal of Psychoanalytic Psychology 3:(Psychoanalysis monograph 1).

Fine, R. (1973) Bobby Fischer's conquest of the world's chess championship. The psychology and tactics of the title match. London: G. Bell \& Sons.

Fink, E. (1957) Oase des Glücks. Gedanken zu einer Ontologie des Spiels. Freiburg: Karl Alber.

Galitis, I. (2002) "Stalemate. Girls and a mixed-gender chess club", Gender and Education 14 (1):71-83. https://doi.org/10.1080/09540250120098898

Gerdes, C. \& P. Gränsmark (2010) "Strategic behavior across gender. A comparison of female and male expert chess players", Labour Economics 17 (5):766-775. https://doi.org/10.1016/j.labeco.2010.04.013

Gizycki, J. (1961[1960]) Stora schackboken. Schackets kulturhistoria kompletterad med svensk schackhistorik av Gideon Ståhlberg. Stockholm: Fröléens.

Gobet, F. (2019) The psychology of chess. New York: Routledge.

Goffman, E. (1961) Encounters. Two studies in the sociology of interaction. Indianapolis: Bobbs-Merrill.

Goffman, E. (1974) Frame analysis. An essay on the organization of experience. Cambridge, Massachusetts: Harvard University Press.

Goffman, E. (1990[1956]) The presentation of self in everyday life. London: Penguin.

Grønn, A. (2017) "Sjakkspelaren Østerberg", Dag og Tid, 3 mars 2017.

Habermas, J. (1987[1981]) Theorie des kommunikativen Handelns. Band 1: Hand- 
lungsrationalität und gesellschaftliche Rationalisierung. Frankfurt am Main: Suhrkamp.

Habermas, J. (1989) Vorstudien und Ergänzungen zur Theorie des kommunikativen Handelns. Frankfurt am Main: Suhrkamp.

Hall, J. (2001) Träna schack med Jesper Hall. Stockholm: Natur och Kultur.

Hallman, J.C. (2003) The chess artist. Genius, obsession, and the world's oldest game. New York: St. Martin's.

Hannak, J. (1991[1952]) Emanuel Lasker. The life of a chess master. New York: Dover.

Hegselmann, R. (1995) "Spieltheorie" i Historisches Wörterbuch der Philosophie. Basel: Schwabe. https://doi.org/10.24894/hwph.4006

Henricks, T.S. (2006) Play reconsidered. Sociological perspectives on human expression. Urbana: University of Illinois Press.

Henricks, T.S. (2015) Play and the human condition. Urbana: University of Illinois Press.

Hoffman, P. (2007) King's gambit. A son, a father, and the world's most dangerous game. Boston: Hachette.

Holländer, H. (2003) "Wildwechsel von Ideen. Über Wihelm Steinitz und Emanuel Lasker", 95-115 i E.-V. Kotowski, S. Poldauf och P.W. Wagner (red.) Emanuel Lasker. Homo ludens - homo politicus. Beiträge über sein Leben und Werk. Potsdam: Verlag für Berlin-Brandenburg.

Hooper, D. \& K. Whyld (1984) The Oxford companion to chess. Oxford: Oxford University Press.

Huizinga, J. (2001[1938]) Homo Ludens. Vom Ursprung der Kultur im Spiel. Hamburg: Rowolt

Hörberg, B. \& J. Westberg (1961) Wilhelm Steinitz. Den förste officielle världsmästaren. 100 utvalda partier och biografi. Stockholm: Forum.

Johnson, J.E., S.G. Eberle, T.S. Henricks \& D. Kuschner (2015) The handbook of the study of play. Band 1-2. Lanham: Rowman \& Littlefield.

Kant, I. (2003[1790]) Kritik av omdömeskraften. Stockholm: Thales.

Kasparov, G. (2018[2017]) Deep thinking. Where machine intelligence ends and human creativity begins. London: John Murray.

Klaus, G. (1965). "Emanuel Lasker. Ein philosophischer Vorläufer der Spieltheorie", Deutsche Zeitschrift für Philosophie 13 (8):976-988. https://doi.org/10.1524/dzph.1965.13.8.976

Kotowski, E.-V., S. Poldauf \& P.W. Wagner (red.) (2003) Emanuel Lasker. Homo ludens - homo politicus. Beiträge über sein Leben und Werk. Potsdam: Verlag für BerlinBrandenburg.

Krause, U. (2001) ''Lasker verliert mitunter eine Partie, aber niemals den Kopf.' Emanuel Lasker als Schachspieler und Schachdenker", 55-88 i M. Dreyer \& U. Sieg (red.) Emanuel Lasker. Schach, Philosophie, Wissenschaft. Berlin: Philo.

Leifer, E.M. (1988) "Trails of involvement. Evidence for local games", Sociological Forum 3 (4):499-524.

"Lång rockad. Badour Jobava" (2017) Tidskrift för schack 122 (2):57. 
Mead, G.H. (1967[1934]) Mind, self, and society. From the standpoint of a social behaviorist. C.W. Morris (red.). Chicago: The University of Chicago Press.

Opfermann, H.C. (1982[1978]) Die Spielgeheimnisse der großen Schachkämpfer. Von Gioachino Greco bis zur Gegenwart. München: Heyne.

Otnes, P. (2006) "Dag Østerberg - determination through ruptures. The dialectics of post-positivism", Acta Sociologica 49 (1):19-28. https://doi.org/10.1177/0001699306061897

Peirce, C.S. (1992[1878]) "How to make our ideas clear", 124-141 i N. Houser \& C.J.W. Kloesel (red.)The essential Peirce. Selected philosophical writings, volume 1 (1867-1893). Bloomington: Indiana University Press.

Persson, A. (2015) "Online schack och chatt interaktion. Spel och spelande i schack ansikte-mot-ansikte och online”, 65-82 i H. Rahm (red.) Vetenskapssocieteten i Lund. Arsbok 2016. Lund: Vetenskapssocieteten.

Petzold, J. (1986) Schach. Eine Kulturgeschichte. Leipzig: Edition Leipzig.

Puddephatt, A.J. (2003) "Chess playing as strategic activity", Symbolic Interaction 26 (2):263-284. https://doi.org/10.1525/si.2003.26.2.263

Puddephatt, A.J. (2008) "Incorporating ritual into greedy institution theory. The case of devotion in amateur chess", The Sociological Quarterly 49 (1):155-180. https://doi.org/10.1111/j.1533-8525.2007.00110.x

Puddephatt, A. \& G.A. Fine (2013) "Chess as art, science, and sport", 390-404 i D.L. Andrews \& B. Carrington (red.) A companion to sport. Oxford: John Wiley \& Sons. https://doi.org/10.1002/9781118325261.ch23

Réti, R. (2002[1922]) Modern ideas in chess. The road along which chess has travelled. Devon: Hardinge Simpole.

Réti, R. (2012[1930]) Masters of the chessboard. Milford: Russell.

Russell, W. \& E. Ryall (2015) "Philosophizing play", 139-159 i J.E. Johnson, S.G. Eberle, T.S. Henricks \& D. Kuschner (red.) The handbook of the study of play. Lanham: Rowman \& Littlefield.

Sala, G. \& F. Gobet (2016) "Do the benefits of chess instruction transfer to academic and cognitive skills? A meta-analysis", Educational Research Review 18:46-57. https://doi.org/10.1016/j.edurev.2016.02.002

Sala, G. \& F. Gobet (2017) "Does chess instruction improve mathematical problemsolving ability? Two experimental studies with an active control group", Learning \& Behavior 45 (4):414-421. https://doi.org/10.3758/s13420-017-0280-3

Shahade, J. (2005) Chess bitch. Women in the ultimate intellectual sport. Los Angeles: Siles. Shenk, D. (2007) The immortal game. A history of chess. Toronto: Anchor Canada.

Skjervheim, H. (1960[1957]) "Deltakar og tilskodar", 63-84 i A. Aarnes, A. Næss, B. Vestre, H. Skjervheim, S. Mehren, K.E. Tranøy \& E.A. Wyller Brytninger $i$ tidens tankeliv. Oslo: Tanum.

Steinbeck, J. (1954) Sweet thursday. London: Heinemann.

Strouhal, E. (2000[1996]) Schach. Die Kunst des Schachspiels. Hamburg: Nikol.

Sundbø, S. (1999) Dag Østerberg. En kronologisk bibliografi over forfatterskapet 19551999. Oslo: Nasjonalbiblioteket. 
Sutton-Smith, B. (1997) The ambiguity of play. Cambridge, Massachusetts: Harvard University Press.

Swedberg, R. (2001) "Sociology and game theory. Contemporary and historical perspectives", Theory and Society 30 (3):301-335. https://doi.org/10.1023/A:1017532512350

Weinreb, M. (2007) The kings of New York. New York: Gotham.

Wendling, T. (1996) "Jouer avec le temps. La pendule des joueurs d'échecs", L'Homme 36 (138):87-109. https://doi.org/10.3406/hom.1996.370075

Wide, S. (2007) "Kan man anklaga en filosof för fusk?", Axess (1):13.

Wide, S. (2017) "Max Scheler på norska? Om ursprunget till 'Deltakar og tilskodar", Norsk sosiologisk tidsskrift 1 (5):365-379.

https://doi.org/10.18261/issn.2535-2512-2017-05-02

Wittgenstein, L. (1978 [1953]) Filosofiska undersökningar. Stockholm: Bonniers.

Zweig, S. (1974[1943]) Schachnovelle. Frankfurt am Main: Fischer.

Øfsti, A. \& D. Østerberg (1982) "Self-defeating predictions and the fixed-point theorem: A refutation", Inquiry 25 (3):331-352. https://doi.org/10.1080/00201748208601971

Østerberg, D. (1977a[1966]) Förståelseformer. Ett filosofiskt bidrag. Göteborg: Korpen.

Østerberg, D. (1977b) Samfunnsmotsetninger. Et samfunnsetisk essay. Oslo: TanumNorli.

Østerberg, D. (1988) Metasociology. An inquiry into the origins and validity of social thought. Oslo: Norwegian University Press.

Østerberg, D. (1993a[1991]) "Bemerkninger om Colemans Foundations of social theory", 249-258 i Fortolkende sosiologi 1. Almene emner og metodologi. Oslo: Universitetsforlaget.

Østerberg, D. (1993b[1986]) Fortolkende sosiologi 1. Almene emner og metodologi. Oslo: Universitetsforlaget.

Østerberg, D. (1993c[1963]) "Metasosiologisk essay", 11-61 i Fortolkende sosiologi 1. Almene emner og metodologi. Oslo: Universitetsforlaget.

Østerberg, D. (1993d[1986]) "Selvbekjempende forutsigelser og nøyaktige sosiologiske lover", 179-193 i Fortolkende sosiologi 1. Almene emner og metodologi. Oslo: Universitetsforlaget.

Østerberg, D. (1993e[1986]) "Sosial interaksjon og spillteorien. Sjakkspillets eksempel”, 195-209 i Fortolkende sosiologi 1. Almene emner og metodologi. Oslo: Universitetsforlaget.

Østerberg, D. (1993f[1980]) "Sosiologi og strategisk tenkning", 213-238 i Fortolkende sosiologi 1. Almene emner og metodologi. Oslo: Universitetsforlaget.

Østerberg, D. (2011) "Ludwig von Mises", 75-104 i H. Friis Nilsen \& C.A. Smedshaug (red.) Troen på markedet. De nyliberale strateger. Oslo: Res Publica.

\section{Författarpresentation}

Sverre Wide är docent i sociologi och lektor vid Örebro universitet. Hans huvudsakliga forskningsintresse är riktat mot relationen mellan socialitet och tänkande samt mot förklaringsmodeller inom samhällsvetenskaperna. 


\section{Kontaktuppgifter författare}

Sverre Wide

Institutionen för humaniora, utbildnings- och samhällsvetenskap 70182 Örebro

sverre.wide@oru.se 